\title{
ANALISIS SISTEM ANTRIAN PADA PELAYANAN POLI JANTUNG RSUD KOTA LANGSA
}

\author{
Fazrina Saumi ${ }^{1}$, Rizki Amalia ${ }^{2}$, Amelia ${ }^{3}$, Nurviana ${ }^{4}$ \\ 1,2,3,4 Universitas Samudra, Langsa \\ fazrinasaumi@unsam.ac.id
}

\begin{abstract}
Queving is an activity where parties are waiting to get service. A queuing process starts from the time of arrival to the time of service. Queuing problems are often encountered in everyday life, including in Langsa City Hospital, especially in the cardiac clinic, which has the most patients. The majority of patients in the queve system are elderly (elderly), so good service is needed considering the physical condition of patients who have entered a vulnerable age. The queuing system analysis aims to determine the average number of patients waiting in the system and the length of service at the heart clinic of Langsa City Hospital. In addition, the queve system analysis can help the Langsa City Hospital design an operational service system so that the service process can run optimally. The queve structure model used is a single channel-single phase with the discipline type First In First Out (FIFO). From the queve model analysis results obtained, the cardiac poly care system has an average number of patients waiting at most occurs in the period 08.00-10.00, namely 14 people with a waiting time of about 56.28 minutes. This time is the busy working hour at cardiac poly with a busyness rate of $93 \%$. From the simulation results with two servers using the same model, a busy rate of $50 \%$ was obtained with a reduction in the number of people waiting by 12.8 people with a waiting time of about 1.2 minutes.
\end{abstract}

Keywords: Queve, single channel-single phase, FIFO, Hearth poly

\begin{abstract}
ABSTRAK Antrian merupakan kegiatan adanya pihak yang menunggu untuk mendapatkan layanan. Suatu proses antrian dimulai dari waktu kedatangan hingga waktu pelayanan. Masalah antrian sering dijumpai pada kehidupan sehari-hari, termasuk di RSUD Kota Langsa khususnya di bagian poli jantung yang memiliki pasien terbanyak. Mayoritas pasien dalam sistem antrian tersebut adalah para lansia (lanjut usia), sehingga diperlukan layanan yang baik mengingat kondisi fisik pasien yang sudah memasuki usia rentan. Analisis sistem antrian bertujuan untuk mengetahui rata-rata jumlah pasien yang menunggu dalam sistem dan lamanya waktu pelayanan di poli jantung RSUD Kota Langsa. Selain itu analisis sistem antrian dapat membantu pihak RSUD Kota Langsa untuk merancang sistem operasional pelayanan agar proses pelayanan dapat berjalan secara optimal. Model struktur antrian yang digunakan adalah single channel-single phase dengan tipe disiplin antrian First In First Out (FIFO). Dari hasil analisis model antrian yang diperoleh, sistem pelayanan poli jantung memiliki rata-rata jumlah pasien menunggu paling banyak terjadi pada periode waktu 08.00-10.00 yaitu 14 orang dengan waktu tunggu sekitar 56,28 menit. Periode waktu tersebut merupakan jam sibuk kerja di poli jantung dengan tingkat kesibukan sebesar 93\%. Dari hasil simulasi dengan dua server menggunakan model yang sama diperoleh tingkat kesibukan sebesar $50 \%$ dengan pengurangan jumlah orang yang menunggu sebesar 12,8 orang dengan waktu tunggu sekitar 1,2 menit.
\end{abstract}

Kata-kata Kunci : Antrian, single channel-single phase, FIFO, Poli Jantung 


\section{PENDAHULUAN}

Antrian merupakan kegiatan yang sering dijumpai sehari-hari. Antrian terjadi ketika terdapat pihak yang menunggu untuk mendapatkan layanan. Suatu proses antrian dimulai dari kedatangan seorang pasien pada suatu fasilitas layanan, menunggu dalam suatu baris jika semua pelayanannya sibuk, dan akhirnya meninggalkan fasilitas tersebut setelah dilayani. Antrian tersebut terjadi ketika jumlah pengunjung di tempat antrian bertambah banyak yang diakibatkan oleh pelayanan petugas yang sangat lambat dan jumlah petugas tidak sebanding dengan jumlah pengunjung yang terdapat pada antrian. Hal itu juga sering terjadi pada layanan di Rumah Sakit.

Menurut Permenkes No 129 tahun 2008 Rumah Sakit sebagai salah satu fasilitas pelayanan kesehatan perorangan merupakan bagian dari sumber daya kesehatan yang sangat diperlukan dalam mendukung penyelenggaraan upaya kesehatan. Rumah sakit juga merupakan suatu unit usaha jasa yang memberikan jasa pelayanan sosial dibidang medis klinis. Rumah sakit adalah tempat untuk melakukan upaya meningkatkan kesehatan, mencegah dan menyembuhkan penyakit, serta memulihkan kesehatan. Sama halnya seperti yang Pengelolaan unit usaha rumah sakit memiliki keunikan tersendiri karena selain sebagai unit bisnis, usaha rumah sakit juga memiliki misi sosial yang berperan penting dalam hal kesehatan masyarakat. Demikian juga halnya dengan Rumah Sakit Umum Daerah Kota Langsa (RSUD).

Bentuk pelayanan rumah sakit dibagi atas pelayanan dasar, pelayanan spesialistik dan sub spesialistik dan pelayanan penunjang. Pelayanan dasar RSUD Kota Langsa terdiri dari layanan rawat jalan (politeknik/ambulatory), rawat inap (inpatient care), dan rawat darurat (emergency care). Untuk layanan rawat jalan, RSUD Kota Langsa memberikan beberapa layanan yaitu : poli orthopedy, anak, kebidanan, bedah, THT, Paru, Penyakit Dalam Pria dan Wanita, mata, diagnostik, kulit, neurologi, gigi, jiwa, umum, dan jantung. Dari keseluruhan poli tersebut, RSUD Kota Langsa memiliki pasien terbanyak di poli jantung. Poli ini hanya melayani pasien pada hari selasa dan kamis. Oleh karena itu, setiap waktu pelayanan poli jantung memiliki antrian pasien yang sangat panjang. Hal ini dapat menyebabkan kejenuhan pasien dalam mengantri untuk mendapatkan pelayanan kesehatan.

Untuk mengatasi fenomena di atas, maka peneliti ingin menganalisis sistem antrian pelayanan poli jantung RSUD Kota Langsa saat ini dan menganalisis model antrian di poli jantung tersebut apabila ditambahkan satu server pelayanan. Diharapkan analisis mode antrian dapat membantu pihak RSUD Kota Langsa dalam merancang sistem operasional pelayanan tersebut agar proses pelayanan dapat berjalan secara optimal, yaitu dengan memberikan pelayanan yang baik dan sesuai standar yang ditetapkan.

Rumusan masalah pada penelitian ini adalah bagaimana hasil analisis sistem antrian yang terbentuk dari fenomena antrian pada poli jantung RSUD Kota Langsa dan sistem manakah yang optimal pada pelayanan poli jantung RSUD Kota Langsa 
Adapun batasan masalah dalam penelitian ini adalah:

1. Disiplin antrian yang digunakan adalah First In-First Out (FIFO) dimana pasien yang dilayani terlebih dahulu adalah pasien yang datang lebih awal.

2. Struktur antrian yang digunakan mengikuti model Single Channel-Single Phase dan Multi Channel Single Phase.

3. Sumber kedatangan pasien adalah tak terbatas

Tujuan dari penelitian ini adalah untuk menganalisis sistem antrian di poli jantung RSUD Kota Langsa dan untuk mengetahui sistem antrian yang optimal pada pelayanan pasien poli jantung RSUD Kota Langsa.

\section{METODE PENELITIAN}

Metode yang digunakan pada penelitian ini adalah dengan mengamati langsung system Antrian yang terjadi di RSUD Kota Langsa. Peneliti mencatat aktivitas sistem antrian mulai dari waktu kedatangan pasien, lama waktu menunggu dipanggil oleh petugas layanan dan lama waktu pelayanan. Penelitian ini dilaksanakan pada tanggal 5 Mei 2018 sampai dengan 12 juli 2018. Tahapan-tahapan yang dilakukan dalam pembentukan model antrian pada penelitian ini adalah sebagai berikut:

1. Mencatat waktu kedatangan pasien. Dari data waktu kedatangan pasien didapatkan data jumlah kedatangan pasien perjam.

2. Mencatat waktu mulai dan selesai dilayani oleh fasilitas pelayanan atau petugas layanan. Dari data ini dihasilkan data lama waktu pasien dilayani oleh masingmasing fasilitas pelayanan atau petugas layanan.

3. Menentukan Karakteristik Antrian

Menurut Siagian (1987), terdapat beberapa karakteristik operasi dalam antrian yaitu:

a. Laju kedatangan pasien

Laju kedatangan pasien adalah rata-rata banyaknya pasien yang datang dalam interval waktu tertentu. Laju kedatangan pasien dinotasikan dengan $\lambda$

b. Laju pelayanan

Laju pelayanan adalah rata-rata banyaknya pasien yang meninggalkan sistem dalam interval waktu tertentu. Laju kedatangan pasien dinotasikan dengan $\mu$

c. Periode Sibuk

Jika mekanisme pelayanan sibuk, dapat dikatakan bahwa sistem antrian sedang dalam periode sibuk. Peluang bahwa sistem antrian sedang dalam keadaan sibuk pada saat random, dinamakan peluang periode sibuk. Peluang periode sibuk dari sistem antrian dengan pelayanan tunggal sama dengan intensitas lalu - lintas. Oleh karena itu bila Pmerupakan fungsi peluang periode sibuk, maka persamaan fungsi peluang periode sibuk adalah :

$$
P=\rho=\frac{\lambda}{\mu}
$$

d. Distribusi Peluang Adanya Pelanggan di Sistem

Berdasarkan persamaan (1) bila $\rho$ merupakan peluang bahwa sistem antrian adalah sibuk, maka 1 - $\rho$ merupakan peluang sistem tidak dalam keadaan 
sibuk pada waktu random. Artinya $1-\rho$ merupakan peluang sistem antrian tidak mempunyai langganan. Misalnya $P_{n}$ merupakan peluang adanya $n$ langganan antrian, maka untuk $n=0, P_{0}=1-\rho$. Karena $P_{n}=\rho^{n} \cdot P_{0}$, maka persamaan peluang dari $n$ langganan sisitem adalah sebagai berikut :

$$
P_{n}=\rho^{n}(1-\rho)
$$

Asumsi yang harus dipenuhi adalah waktu antar kedatangan dan waktu pelayanan mempunyai sebaran diskrit.

e. Jumlah Rata-rata dalam Sistem

Misalkan $E\left(n_{t}\right)$ berupa jumlah rata-rata pelanggan dalam sistem antrian, mencakup pelanggan yang menunggu dan yang sedang dilayani. Maka berdasarkan persamaan (2),

$$
\begin{aligned}
E\left(n_{t}\right) & =\sum_{n=0}^{\infty} n P_{n} \\
& =\sum_{n=0}^{\infty} n\left(\frac{\lambda}{\mu}\right)^{n}\left(1-\frac{\lambda}{\mu}\right) \\
& =\left(1-\frac{\lambda}{\mu}\right) \sum_{n=0}^{\infty} n\left(\frac{\lambda}{\mu}\right)^{n}
\end{aligned}
$$

f. Jumlah Rata-rata dalam Antrian

Rata-rata banyaknya pelanggan dalam antrian adalah rata-rata banyaknya pelanggan yang menunggu untuk mendapatkan pelayanan (tidak termasuk yang sedang dilayani) pada selang waktu tertentu. Misalkan $E\left(n_{w}\right)$ sebagai jumlah rata-rata pelanggan dalam antrian, maka berdasarkan persamaan (3), persamaan $E\left(n_{w}\right)$ adalah sebagai berikut :

$$
\begin{aligned}
E\left(n_{w}\right) & =E\left(n_{t}\right)-\frac{\lambda}{\mu} \\
& =\frac{\lambda}{\mu-\lambda}-\frac{\lambda}{\mu} \\
& =\frac{\lambda^{2}}{\mu(\mu-\lambda)} \\
& =\frac{\rho^{2}}{1-\rho}
\end{aligned}
$$

g. Jumlah Rata-rata banyaknya pelanggan dalam Sistem

Rata-rata banyaknya pelanggan dalam sistem adalah rata-rata banyaknya pelanggan yang menunggu untuk dilayani dan pelanggan yang menunggu utnuk dilayani dan pelanggan yang sedang dilayani dalam selang waktu tertentu. Misalkan $E\left(n_{t}\right)$ berupa jumlah rata-rata langganan dalam sistem antrian dan mencakup langganan yang menunggu dan yang sedang dilayani. Maka persamaan jumlah rata-rata dari sistem adalah sebagai berikut:

$$
\begin{aligned}
E\left(n_{t}\right) & =\sum_{n=0}^{\infty} n P_{n} \\
& =\sum_{n=0}^{\infty} n\left(\frac{\lambda}{\mu}\right)^{n}\left(1-\frac{\lambda}{\mu}\right) \\
& =\left(1-\frac{\lambda}{\mu}\right) \sum_{n=0}^{\infty} n\left(\frac{\lambda}{\mu}\right)^{n}
\end{aligned}
$$


h. Waktu Rata-rata dalam Antrian

Misalkan $E\left(T_{w}\right)$ merupakan waktu rata-rata yang dihabiskan oleh seorang pelanggan dalam antrian, maka berdasarkan persamaan (4), $E\left(T_{w}\right)$ adalah sebagai berikut :

$$
\begin{aligned}
E\left(T_{w}\right) & =\frac{E\left(n_{w}\right)}{\lambda} \\
& =\frac{1}{\lambda} \frac{\lambda^{2}}{\mu(\mu-\lambda)} \\
& =\frac{\lambda}{\mu(\mu-\lambda)}
\end{aligned}
$$

i. Waktu Rata-rata dalam Sistem

Misalkan $E\left(T_{t}\right)$ merupakan waktu rata-rata bahwa seorang pelanggan akan menghabiskan waktunya dalam sistem, maka $E\left(T_{t}\right)=\frac{E\left(n_{t}\right)}{\lambda}$ dimana $E\left(n_{t}\right)$ adalah jumlah rata-rata pelanggan dalam sistem. Jadi persamaan waktu rata-rata dalam sistem adalah sebagai berikut ini :

$$
\begin{aligned}
E\left(T_{t}\right) & =\frac{\frac{\lambda}{\mu-\lambda}}{\lambda} \\
& =\frac{1}{\mu-\lambda}
\end{aligned}
$$

j. Waktu Pelayanan Rata-rata

Misalkan $E\left(T_{s}\right)$ merupakan waktu rata-rata yang diperlukan oleh seorang pelanggan untuk menerima pelayanan, maka persamaannya adalah sebagai berikut ini:

$$
E\left(T_{s}\right)=\frac{E\left(n_{s}\right)}{\lambda} \quad=\frac{\rho}{\lambda}=\frac{\frac{\lambda}{\mu}}{\lambda}=\frac{1}{\mu}
$$

4. Menguji sebaran data waktu antar kedatangan pasien dan waktu pelayanan dengan uji Kolmogorov-Smirnov. Apabila asumsi sebaran data tidak terpenuhi maka mencari sebaran yang sesuai dengan data.

5. Diperoleh model antrian yang sesuai dengan sebaran data. Pemilihan model antrian berdasarkan simbol-simbol dari Notasi Kendall-Lee. Notasi baku untuk memodelkan teori antrian pertama sekali dikemukakan D.G.Kendall dan A.M Lee dengan notasi a/b/c/d/e. Menurut Taha (1997), notasi Kendall-Lee tersebut perlu ditambahkan symbol $\mathrm{f}$, sehingga karakteristik antrian dapat dinotasikan dalam format baku a/b/c/d/e/f. Notasi a sampai $f$ dapat digantikan dengan symbolsimbol pada tabel 1. 
Tabel 1. Simbol - simbol Pengganti Notasi Kendall-Lee

\begin{tabular}{|c|c|c|}
\hline Notasi & Simbol & Keterangan \\
\hline \multirow[t]{5}{*}{$a$ dan $b$} & M & $\begin{array}{l}\text { Markov menyatakan kedatangan } \\
\text { dan kepergian berdistribusi poisson } \\
\text { (waktu antar kedatangan } \\
\text { berdistribusi eksponensial) }\end{array}$ \\
\hline & $\mathrm{D}$ & $\begin{array}{l}\text { Deterministik menyatakan waktu } \\
\text { antar kedatangan atau waktu } \\
\text { pelayanan konstan }\end{array}$ \\
\hline & $E_{k}$ & $\begin{array}{l}\text { Waktu antar kedatangan atau waktu } \\
\text { pelayanan berdistribusi Erlang }\end{array}$ \\
\hline & Gl & $\begin{array}{l}\text { Distribusi Independen umum dari } \\
\text { kedatangan (atau waktu antar } \\
\text { kedatangan) }\end{array}$ \\
\hline & G & $\begin{array}{l}\text { Distribusi Umum dari waktu } \\
\text { pelayanan }\end{array}$ \\
\hline \multirow[t]{4}{*}{$\mathrm{D}$} & FCFS/FIFO & $\begin{array}{l}\text { First Come First Served (FCFS) atau } \\
\text { First In First out (FIFO) }\end{array}$ \\
\hline & LCFS/LIFO & $\begin{array}{l}\text { Last Come First Served (LCFS) atau } \\
\text { Last In First Out (LIFO) }\end{array}$ \\
\hline & SIRO & Service In Random Order (SIRO) \\
\hline & PS & Priority Service (PS) \\
\hline$c, e, f$ & $1,2,3$ & \\
\hline
\end{tabular}

6. Melakukan simulasi dengan model yang sama untuk dua server/pelayanan.

\section{HASIL DAN PEMBAHASAN}

Tingkat Kedatangan Pasien dan Tingkat Pelayanan Poli

Rata-rata tingkat kedatangan pasien dan rata-rata tingkat pelayanan poli jantung di RSUD Kota Langsa:

Tabel 2. Data Rata-Rata Tingkat Kedatangan Pasien

\begin{tabular}{lll}
\hline \multirow{2}{*}{$\begin{array}{l}\text { Periode Wam) } \\
\text { (jamtu }\end{array}$} & \multicolumn{2}{l}{ Kedatangan Pasien (orang) } \\
\cline { 2 - 3 } & $\begin{array}{l}\text { Jumlah kedatangan } \\
\text { selama 16 hari }\end{array}$ & $\begin{array}{l}\text { Rata - Rata } \\
\text { Kedatangan } \\
\text { Pasien }\end{array}$ \\
\hline $07.00-08.00$ & 160 & 10 \\
\hline $08.00-09.00$ & 230 & 14 \\
\hline $09.00-10.00$ & 217 & 14 \\
\hline $10.00-11.00$ & 113 & 7 \\
\hline $11.00-12.00$ & 25 & 2 \\
\hline Sumber: Data Diolah (2018) &
\end{tabular}


Tabel 3. Data Rata-Rata Tingkat Pelayanan

\begin{tabular}{|c|c|c|}
\hline $\begin{array}{l}\text { Periode } \\
\text { Waktu }\end{array}$ & $\begin{array}{l}\text { Rata-rata } \\
\text { waktu } \\
\text { pelayanan }\end{array}$ & $\begin{array}{l}\text { Tingkat } \\
\text { Pelayanan }\end{array}$ \\
\hline $07.00-08.00$ & \multirow{5}{*}{4 Menit } & \multirow{5}{*}{$\begin{array}{l}15 \quad \text { orang } \\
\text { (diperoleh dari } 60 \\
\text { menit/rata-rata } \\
\text { waktu } \\
\text { pelayanan) }\end{array}$} \\
\hline $08.00-09.00$ & & \\
\hline $09.00-10.00$ & & \\
\hline $10.00-11.00$ & & \\
\hline $11.00-12.00$ & & \\
\hline
\end{tabular}

Sumber: Data Diolah (2018)

\section{Uji Kesesuaian dan Model}

Pengujian ini menggunakan uji Kolmogorov Smirnov untuk menguji apakah jumlah kedatangan pasien berdistribusi Poisson dan waktu pelayanan berdistribusi Exponential. Pengujian ini akan membandingkan antara nilai signifikansi (Asymp.Sig) dengan nilai $\alpha$ (taraf nyata) yang telah ditetapkan yaitu 0.05. Jika nilai signifikansi lebih besar dari taraf nyata yang telah ditetapkan maka hipotesis distribusi pengujian diterima, sebaliknya jika nilai signifikansi lebih kecil dari taraf nyata maka hipotesis distribusi pengujian ditolak.

Hipotesis yang akan diuji untuk data jumlah kedatangan pasien adalah sebagai berikut:

$\mathrm{H}_{0}$ : Pola kedatangan pasien berdistribusi Poisson

$\mathrm{H}_{1}$ : Pola kedatangan pasien tidak berdistribusi Poisson

Pola kedatangan yang akan diuji adalah jumlah kedatangan pasien per jam, yang dimulai dari jam $07.00 \mathrm{~s} / \mathrm{d}$ 12.00. Hasil pengujian hipotesis dapat dilihat pada tabel 4 di bawah ini :

Tabel 4. One-Sample Kolmogorov-Smirnov Test

\begin{tabular}{|c|c|c|c|c|c|c|}
\hline & \multicolumn{5}{|c|}{ Kedatangan Pasien Per Jam } \\
\hline & & $07.00-$ & $08.00-$ & $09.00-$ & $10.00-$ & $11.00-$ \\
\hline & & 08.00 & 09.00 & 10.00 & 11.00 & 12.00 \\
\hline \multicolumn{2}{|l|}{$N$} & 16 & 16 & 16 & 16 & 16 \\
\hline \multirow{2}{*}{\multicolumn{2}{|c|}{$\begin{array}{l}\text { Poisson } \\
\text { Parametera,b }\end{array}$}} & \multirow{2}{*}{10,00} & \multirow{2}{*}{14,38} & \multirow{2}{*}{13,56} & \multirow{2}{*}{7,06} & \multirow{2}{*}{1,56} \\
\hline & & & & & & \\
\hline Most Extreme & Absolute & 245 & 407 & 231 &, 105 &, 165 \\
\hline \multirow[t]{2}{*}{ Differences } & Positive & 245 & 407 & ,231 &, 098 &, 165 \\
\hline & Negative &,- 173 &,- 181 &,- 190 &,- 105 &,- 103 \\
\hline \multicolumn{2}{|c|}{ Kolmogorov-Smirnov Z } &, 979 & 1,629 &, 926 &, 421 &, 662 \\
\hline \multicolumn{2}{|c|}{ Asymp. Sig. (2-tailed) } & ,293 & 100 & ,358 &, 994 & ,774 \\
\hline
\end{tabular}


Dari tabel di atas dapat dilihat bahwa nilai asymp. Sig (2-tailed) dari setiap pola kedatangan melebihi dari 0,05 (p.value $>0,05$ ) yang berarti $\mathrm{H}_{0}$ tidak ditolak. Hal ini dapat disimpulkan bahwa pola kedatangan pasien berdistribusi Poisson.

Berikutnya hipotesis untuk waktu pelayanan adalah sebagai berikut:

$\mathrm{H}_{0}$ : Pola waktu pelayanan pasien berdistribusi Exponential

$\mathrm{H}_{1}$ : Pola waktu pelayanan pasien tidak berdistribusi Exponential

Waktu pelayanan dihitung dari pasien mulai dilayani sampai selesai dilayani pada Poli Jantung. Adapun hasil uji hipotesis dari waktu pelayanan dapat dilihat pada tabel 5:

Tabel 5. One-Sample Kolmogorov-Smirnov Test

\begin{tabular}{lll}
\hline & & Pelayanan \\
\hline$N$ & Mean & 16 \\
\hline $\begin{array}{lll}\text { Exponential } \\
\text { parameter. } a, b\end{array}$ & 3,9069 \\
\hline Most Extreme & Absolute &, 444 \\
\cline { 2 - 3 } Differences & Positive &, 184 \\
\cline { 2 - 3 } & Negative &,- 444 \\
\hline Kolmogorov-Smirnov Z & 1,774 \\
\hline Asymp. Sig. (2-tailed) &, 004
\end{tabular}

Pada tabel diatas terlihat bahwa nilai asymp. Sig (2-tailed) untuk waktu pelayanan kurang dari 0,05 (p.value $<0,05$ ) yang berarti hipotesis nol ditolak. Dengan demikian, dapat disimpulkan bahwa waktu pelayanan pasien tidak berdistribusi Exponential atau dengan kata lain waktu pelayanan mengikuti distribusi yang umum.

Berdasarkan hasil analisis maka model antrian yang diperoleh adalah (M/G/1); $(\mathrm{FIFO} / \infty / \infty)$. Hal ini berarti tingkat kedatangan pasien berdistribusi Poisson. Waktu pelayanan dari model tersebut menunjukkan bahwa tidak memenuhi asumsi menyebar secara Exponential. Distribusi waktu pelayanan bersifat umum. Disiplin antrian yang digunakan adalah pasien yang pertama datang yang pertama dilayani tanpa adanya prioritas. Jumlah pasien dalam sistem antrian dan ukuran populasi adalah tak berhingga. Hasil kinerja antrian secara rinci dapat dilihat pada tabel 6.

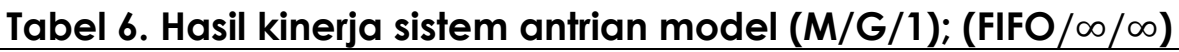

\section{Periode}

Waktu

Parameter

Nilai Menit detik

(Jam)

\begin{tabular}{lc} 
Faktor utilitas sistem & 0,67 \\
\hline $\begin{array}{l}\text { Rata-rata jumlah pasien dalam antrian } \\
\text { (La) }\end{array}$ & 1,34 \\
\hline Rata-rata jumlah pasien dalam sistem (Ls) & 2,01
\end{tabular}




\begin{tabular}{|c|c|c|c|c|}
\hline $\begin{array}{l}\text { Periode } \\
\text { Waktu } \\
\text { (Jam) }\end{array}$ & Parameter & Nilai & Menit & detik \\
\hline & Waktu rata-rata dalam antrian (Wq) & 0,13 & 8,04 & 482,41 \\
\hline & Waktu rata-rata dalam sistem (Ws) & 0,2 & 12,04 & 722,41 \\
\hline \multirow{5}{*}{$08.00-09.00$} & Faktor utilitas sistem & 0,93 & & \\
\hline & $\begin{array}{l}\text { Rata-rata jumlah pasien dalam antrian } \\
\text { (Lq) }\end{array}$ & 13,13 & & \\
\hline & Rata-rata jumlah pasien dalam sistem (Ls) & 14,07 & & \\
\hline & Waktu rata-rata dalam antrian (Wq) & 0,94 & 56,28 & 3376,84 \\
\hline & Waktu rata-rata dalam sistem (Ws) & 1,0 & 60,28 & 3616,84 \\
\hline \multirow{5}{*}{$09.00-10.00$} & Faktor utilitas sistem & 0,93 & & \\
\hline & $\begin{array}{l}\text { Rata-rata jumlah pasien dalam antrian } \\
\text { (Lq) }\end{array}$ & 13,13 & & \\
\hline & Rata-rata jumlah pasien dalam sistem (LS) & 14,07 & & \\
\hline & Waktu rata-rata dalam antrian (Wq) & 0,94 & 56,28 & 3376,84 \\
\hline & Waktu rata-rata dalam sistem (Ws) & 1,0 & 60,28 & 3616,84 \\
\hline \multirow{5}{*}{$10.00-11.00$} & Faktor utilitas sistem & 0,47 & & \\
\hline & $\begin{array}{l}\text { Rata-rata jumlah pasien dalam antrian } \\
\text { (Lq) }\end{array}$ & 0,41 & & \\
\hline & Rata-rata jumlah pasien dalam sistem (Ls) & 0,88 & & \\
\hline & Waktu rata-rata dalam antrian (Wq) & 0,06 & 3,52 & 211,05 \\
\hline & Waktu rata-rata dalam sistem (Ws) & 0,13 & 7,52 & 451,05 \\
\hline \multirow{5}{*}{$11.00-12.00$} & Faktor utilitas sistem & 0,13 & & \\
\hline & $\begin{array}{l}\text { Rata-rata jumlah pasien dalam antrian } \\
\text { (Lq) }\end{array}$ & 0,02 & & \\
\hline & Rata-rata jumlah pasien dalam sistem (Ls) & 0,15 & & \\
\hline & Waktu rata-rata dalam antrian (Wq) & 0,01 & 0,62 & 37,11 \\
\hline & Waktu rata-rata dalam sistem (Ws) & 0,08 & 4,62 & 277,11 \\
\hline
\end{tabular}

Sumber: hasil analisis data dengan menggunakan POM-QM

Berdasarkan tabel 1 diperoleh hasil analisis sistem antrian sebagai berikut.

1. Rata-rata jumlah pasien dalam sistem (LS)

Rata-rata jumlah pasien yang menunggu dalam sistem terpanjang terjadi pada periode waktu 08.00-09.00 dan 09.00-10.00 dimana rata-rata jumlah pasien yang menunggu untuk dilayani di poli sebanyak 14 orang dan rata-rata jumlah pasien dalam antrian terpendek terjadi pada periode waktu 11.00-12.00 dimana jumlah pasien yang menunggu untuk dilayani sebanyak 0,15 orang.

2. Waktu rata-rata yang dihabiskan seorang pasien dalam sistem (Ws)

Waktu terpanjang yang dibutuhkan seorang pasien dalam sistem adalah 60,28 menit yang terjadi pada periode waktu 08.00-09.00 dan 09.00-10.00 dan waktu terpendek adalah 4,62 menit yang terjadi pada periode waktu $11.00-12.00$.

3. Rata-rata jumlah pasien dalam antrian (Lq)

Rata-rata jumlah pasien dalam antrian terpanjang terjadi pada periode waktu 08.0009.00 dan 09.00-10.00 dimana rata-rata jumlah pasien yang mengantri sebanyak 
13,13 orang dan rata-rata jumlah pasien yang dalam antrian terpendek terjadi pada pada periode waktu 11.00-12.00 dimana jumlah pasien yang mengantri sebanyak 0,02 .

4. Waktu rata-rata yang dihabiskan oleh seorang pasien untuk menunggu dalam antrian (Wq)

Waktu terpanjang yang diperlukan pasien dalam antrian 56,28 menit yang terjadi pada periode 08.00-09.00 dan 09.00-10.00 dan waktu terpendek adalah menit 0,62 yang terjadi pada periode 11.00-12.00.

5. Tingkat kesibukan poli (م)

Jam sibuk kerja poli terjadi pada periode waktu 08.00-09.00 dan 09.00-10.00 dimana pada periode tersebut tingkat kesibukan poli sebesar 0,93 atau $93 \%$.

Selanjutnya analisis sistem antrian untuk model yang sama dengan dua server/pelayanan sehingga menjadi model (M/G/2); (FIFO/ $\infty / \infty)$. Adapun hasil perbandingan kinerja sistem antrian kedua model dapat dilihat pada tabel 7.

\begin{tabular}{|c|c|c|c|}
\hline $\begin{array}{l}\text { Periode Waktu } \\
\text { (Jam) }\end{array}$ & Parameter & $M / G / 1$ & $M / G / 2$ \\
\hline \multirow{5}{*}{$07.00-08.00$} & Faktor utilitas sistem & 0,67 & 0,33 \\
\hline & $\begin{array}{l}\text { Rata-rata jumlah pasien dalam antrian } \\
\text { (Lq) }\end{array}$ & 1,34 & 0,08 \\
\hline & $\begin{array}{l}\text { Rata-rata jumlah pasien dalam sistem } \\
\text { (Ls) }\end{array}$ & 2,01 & 0,75 \\
\hline & Waktu rata-rata dalam antrian (Wq) & 0,13 & 0,01 \\
\hline & Waktu rata-rata dalam sistem (Ws) & 0,2 & 0,08 \\
\hline \multirow{5}{*}{$08.00-09.00$} & Faktor utilitas sistem & 0,93 & 0,5 \\
\hline & $\begin{array}{l}\text { Rata-rata jumlah pasien dalam antrian } \\
\text { (Lq) }\end{array}$ & 13,13 & 0,33 \\
\hline & $\begin{array}{l}\text { Rata-rata jumlah pasien dalam sistem } \\
\text { (Ls) }\end{array}$ & 14,07 & 1,33 \\
\hline & Waktu rata-rata dalam antrian (Wq) & 0,94 & 0,02 \\
\hline & Waktu rata-rata dalam sistem (Ws) & 1,0 & 0,09 \\
\hline \multirow{5}{*}{$09.00-10.00$} & Faktor utilitas sistem & 0,93 & 0,47 \\
\hline & $\begin{array}{l}\text { Rata-rata jumlah pasien dalam antrian } \\
\text { (Lq) }\end{array}$ & 13,13 & 0,26 \\
\hline & $\begin{array}{l}\text { Rata-rata jumlah pasien dalam sistem } \\
\text { (Ls) }\end{array}$ & 14,07 & 1,19 \\
\hline & Waktu rata-rata dalam antrian (Wa) & 0,94 & 0,02 \\
\hline & Waktu rata-rata dalam sistem (Ws) & 1,0 & 0,09 \\
\hline \multirow{4}{*}{$10.00-11.00$} & Faktor utilitas sistem & 0,47 & 0,23 \\
\hline & $\begin{array}{l}\text { Rata-rata jumlah pasien dalam antrian } \\
\text { (Lq) }\end{array}$ & 0,41 & 0,03 \\
\hline & $\begin{array}{l}\text { Rata-rata jumlah pasien dalam sistem } \\
\text { (Ls) }\end{array}$ & 0,88 & 0,49 \\
\hline & Waktu rata-rata dalam antrian (Wq) & 0,06 & 0 \\
\hline
\end{tabular}




\begin{tabular}{|c|c|c|c|}
\hline $\begin{array}{l}\text { Periode Waktu } \\
\text { (Jam) }\end{array}$ & Parameter & $M / G / 1$ & $M / G / 2$ \\
\hline & Waktu rata-rata dalam sistem (Ws) & 0,13 & 0,07 \\
\hline \multirow{5}{*}{$11.00-12.00$} & Faktor utilitas sistem & 0,13 & 0,07 \\
\hline & $\begin{array}{l}\text { Rata-rata jumlah pasien dalam antrian } \\
\text { (Lq) }\end{array}$ & 0,02 & 0 \\
\hline & $\begin{array}{l}\text { Rata-rata jumlah pasien dalam sistem } \\
\text { (Ls) }\end{array}$ & 0,15 & 0,13 \\
\hline & Waktu rata-rata dalam antrian (Wq) & 0,01 & 0 \\
\hline & Waktu rata-rata dalam sistem (Ws) & 0,08 & 0,07 \\
\hline
\end{tabular}

sumber: hasil analisis data dengan menggunakan POM-QM

Adanya perbandingan hasil kinerja sistem antrian pada tabel 7 menunjukkan bahwa kinerja sistem antrian untuk model (M/G/2); (FIFO/ $/ \infty)$ dapat lebih mengoptimalkan pelayanan pasien pada poli jantung RSUD Kota Langsa. Hal ini terlihat dari rata-rata jumlah pasien dalam sistem terpanjang yaitu pada waktu 08.00-09.00 berkurang sebanyak 12,74 dan pada waktu 09.00-10.00 berkurang sebanyak 12,88. Rata-rata jumlah pasien dalam antrian pada sistem terpanjang pada waktu 08.00-09.00 berkurang sebanyak 12,8 dan pada waktu 09.00-10.00 berkurang sebanyak 12,87. Waktu rata-rata yang dihabiskan seorang pasien dalam sistem terpanjang yaitu 60 menit berkurang menjadi 5,3 menit per pasien. Sedangkan waktu rata-rata yang dihabiskan seorang pasien dalam antrian adalah 56,28 menit menjadi 1,2 menit. Tingkat kesibukan berkurang dari $93 \%$ menjadi $50 \%$.

\section{KESIMPULAN DAN SARAN}

Berdasarkan hasil pengolahan data, maka penulis menarik beberapa kesimpulan sebagai berikut: 1) Rata-rata waktu pelayanan pada poli jantung RSUD Kota Langsa adalah 3,9058 menit $\approx 4$ menit. Tingkat pelayanan 15 orang (diperoleh dari 60 menit/rata-rata waktu pelayanan). Setelah dilakukan pengolahan data diperoleh hasil bahwa jumlah terbanyak pasien yang menunggu dalam antrian terjadi pada periode 08.00 - 10.00 sebanyak 14 orang dan waktu rata-rata terlama yang dihabiskan oleh seorang pasien dalam antrian selama 56,28 menit; 2) Dari hasil uji kecocokan maka diperoleh model antrian pada fenomena antrian poli jantung RSUD Kota

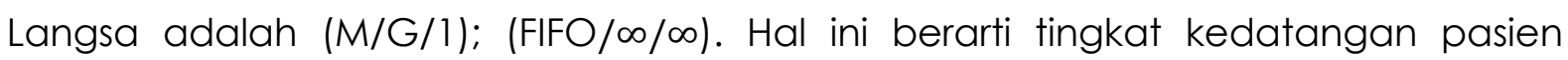
berdistribusi Poisson. Waktu pelayanan dari model tersebut menunjukkan bahwa tidak memenuhi asumsi menyebar secara Exponential. Distribusi waktu pelayanan bersifat umum. Disiplin antrian yang digunakan adalah pasien yang pertama datang yang pertama dilayani tanpa adanya prioritas. Jumlah pasien dalam sistem antrian dan ukuran populasi adalah tak berhingga; 3) Dari hasil simulasi model antrian

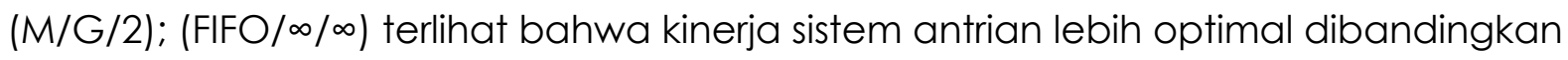

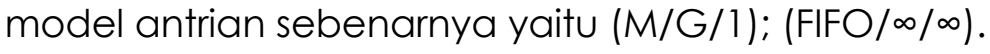




\section{DAFTAR PUSTAKA}

Aditya, R.I , (2014), Pemodelan Sistem Antrian Pengambilan Dana Pensiun di Kantor Pos Cabang Gombong Kabupaten Kebumen Menggunakan Model Antrian Multiple Server- Single Phase, Vol 2, No 5, Jurnal Mahasiswa Statistik.

Ersyad,Z,A \& Devianto, D, (2012). "Identifikasi Model Antrian pada Antrian Bus Kampus Universitas Andalas Padang, Vol 1 No 2, hal 44 - 51, Jurnal Matematika Unand

Kepmenkes (2008). Keputusan Menteri Kesehatan tentang Standar Pelayanan Minimal Rumah Sakit Nomor 129 tahun 2008. Jakarta: [on-line], Tersedia: https://www.slideshare.net/f1smed/kepmenkesno129tahun2008standarpelaya nanminimalrs

Purnawan, D, (2013). Analisis Model Antrian Perbaikan Sepeda Motor dengan Menggunakan Program Visual Basic. Skripsi Universitas Negeri Semarang, Semarang; Tidak diterbitkan

Ross, S.M. 2009. Introduction to Probability Models. Academic Press, New York

Siagian, P, (1987), Penelitian Operasioanal Teori dan Praktek, Universitas Indonesia Press, Jakarta.

Subagyo, P, (1986), Dasar-dasar Operations Research, BPFE, Yogyakarta.

Taha, H.1997. Riset Operasi (Terjemahan Daniel Wirajaya). Jakarta: Binarupa Aksara

Winston, W, (2003), Operations Research Applications and Algorithm. $4^{\text {th }}$ Edision, Duxbury Press, United States. 